\title{
Paper
}

\section{A colorectal cell line with alterations in E-cadherin and epithelial biology may be an in vitro model of colitis}

\author{
I Perry, R Hardy, T Jones, J Jankowski
}

\begin{abstract}
Background-It has been shown previously in ulcerative colitis tissue that E-cadherin can occasionally be mutated in the extracellular domain early in neoplastic progression. E-cadherin is known to maintain differentiation and inhibits invasion in vivo.
\end{abstract}

Aims-To assess the mechanisms by which such dysfunction occurs.

Methods-Four human colorectal cancer cell lines, HCA-7 colonies 1, 3, 6, and 30, derived from a single heterogeneous colorectal cancer were studied. The HCA-7 cell line has p53 mutations and a random errors of replication "positive" phenotype, as is seen in early colitis associated cancers or hereditary nonpolyposis coli cancer (HNPCC).

Results-Cell lines 6 and 30 expressed E-cadherin abundantly and this correlated positively with their degree of differentiation and organisation; however, both cell lines had loss of heterozygosity of E-cadherin. Interestingly, E-cadherin production was downregulated in the poorly differentiated cell line 1 , and this was associated with major chromosomal rearrangements of $16 \mathrm{q}$. This cell line also had a mutation in the homophilic binding domain of exon 4, which was associated with disaggregation by low titres of a function blocking antibody, and an invasive phenotype.

Conclusions-These multiple biological alterations further characterise the complex association that E-cadherin has with tumour heterogeneity and suggest that this series of cell lines may be a useful model of colitis associated or HNPCC associated tumorigenesis.

(F Clin Pathol: Mol Pathol 1999;52:231-242)

Keywords: cancer; colorectal; E-cadherin; HCA-7 cell line; mutations; transitions

Ulcerative colitis is a common disease affecting the colon in Western populations, which can cause severe diarrhoea and rectal bleeding, in addition to abdominal pain. At present, there are no entirely satisfactory treatments for this condition, which also increases the accumula- tion of multiple mutations ${ }^{1}$ and the risk of colorectal cancer. ${ }^{2}$ The common epithelial features of ulcerative colitis include denudation of colorectal cells, abnormal mucosal proliferation, depleted goblet cell lineages, and dysplasia, which may lead to adenocarcinoma. ${ }^{3}$ This differs from the adenoma-carcinoma sequence because the disease is multifocal and arises in the midst of chronic colonic inflammation, with the activation of both regulatory and pro-inflammatory cytokines. Indirect evidence that the main adhesive and occluding junctions (adherens junctions and tight junctions) are perturbed during colitis comes from a report suggesting that mucosal barrier dysfunction and increased permeability is common in ulcerative colitis. ${ }^{4}$

Major developments in animal models of colitis have been reported that might shed some light on damage and repair. In particular, a chimaeric/transgenic murine model expressing a dominant negative $\mathrm{N} / \mathrm{E}$-cadherin results in an inflammatory bowel disease resembling Crohn's colitis. ${ }^{56}$ In humans, it has also been reported recently that chromosome 16 , where both the genes for E-cadherin and P-cadherin are located, is a major susceptibility locus for inflammatory bowel disease. ${ }^{78}$ Our group has recently identified germline mutations of E-cadherin in families with a history of gastric cancer. ${ }^{9}$ In addition, we have also identified E-cadherin mutations in cases of early ulcerative colitis and Crohn's colitis. ${ }^{10}$ Cadherins are a large family of calcium dependent cell-cell adhesion molecules with functions essential to the maintenance of intercellular connections at the zonula adherens junctions. ${ }^{11}$ They are characterised by five conserved repeated amino acid sequences (cadherin repeats) in the extracellular domain, which have a conserved $\alpha$ helix loop $\beta$ barrel structure and a conserved catenin binding domain, by which they are anchored to the cytoskeleton. ${ }^{11-17}$ Cadherins also act as master morphoregulatory molecules that modulate epithelial polarity, cell plasticity, and cell survival during development and remodelling in disease. ${ }^{1318}$ In cancer, including sporadic colorectal cancer, the absence of these molecules is associated with a poor prognosis. $^{9}{ }^{12} 19$ These latter changes in cadherin biology could result from either quantitative and/or functional changes in protein
Accepted for publication 1 May 1999 


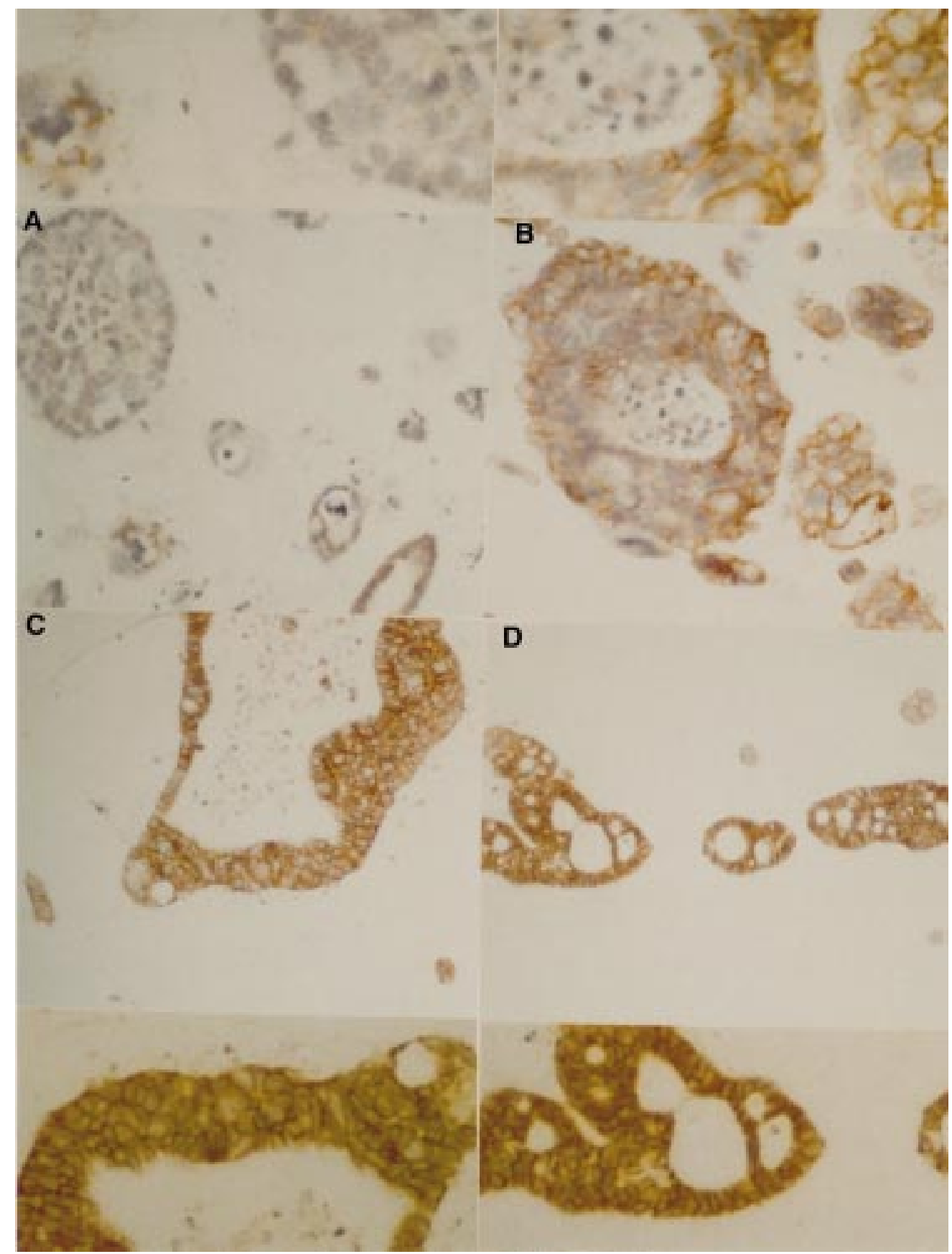

Figure 1 The HCA-7 subcolonies are labelled with E-cadherin antibodies after 15 days growth in collagen gels (magnification, $\times 400-700)$. (A) Colony 1, large poorly organised structures with occasional smaller hollow structures that express E-cadherin weakly. (B) Colony 3, poor organisation is present and only a few hollow spheroids have weak to moderate expression of E-cadherin. (C) Colony 6, glandular structures with strong membranous immunoreactivity and one area of glandular budding (bottom). (D) Colony 30, highly organised single layered glands with strong E-cadherin expression. (High power inserts are placed above and below the central photographs (magnification, $\times 500-1000$.)

concentrations or more subtle but still biologically important mutations to the gene structure, especially at the $5^{\prime}$ end. ${ }^{20}$

Unfortunately, until recently, there have been few approaches to test the pleiomorphic actions of E-cadherin in a single cell model possessing multiple phenotypes and biology. A series of human colorectal cancer cell lines have previously been isolated from a single cell line (HCA-7). ${ }^{21}$ These subcolonies, however, had similar common mutations associated with a transformed phenotype, namely $\mathrm{p} 53$ and random errors of replication (RERs). ${ }^{22}$ These cell lines were different in their morphology, differentiation, growth, and invasive biology in agar and xenografts. ${ }^{21}$ In particular, these xenograft tumours showed differentiation ranging from well differentiated villo/tubular/cystic to poorly differentiated villous. Furthermore, some tumours demonstrated a slow expansive growth in vitro, whereas others showed a rapid infiltrative phenomena. Therefore, it seemed possible that additional genetic changes may be the cause of the varied biological characteristics, regardless of the cellular environment, because biological differences were seen with and without extracel- 


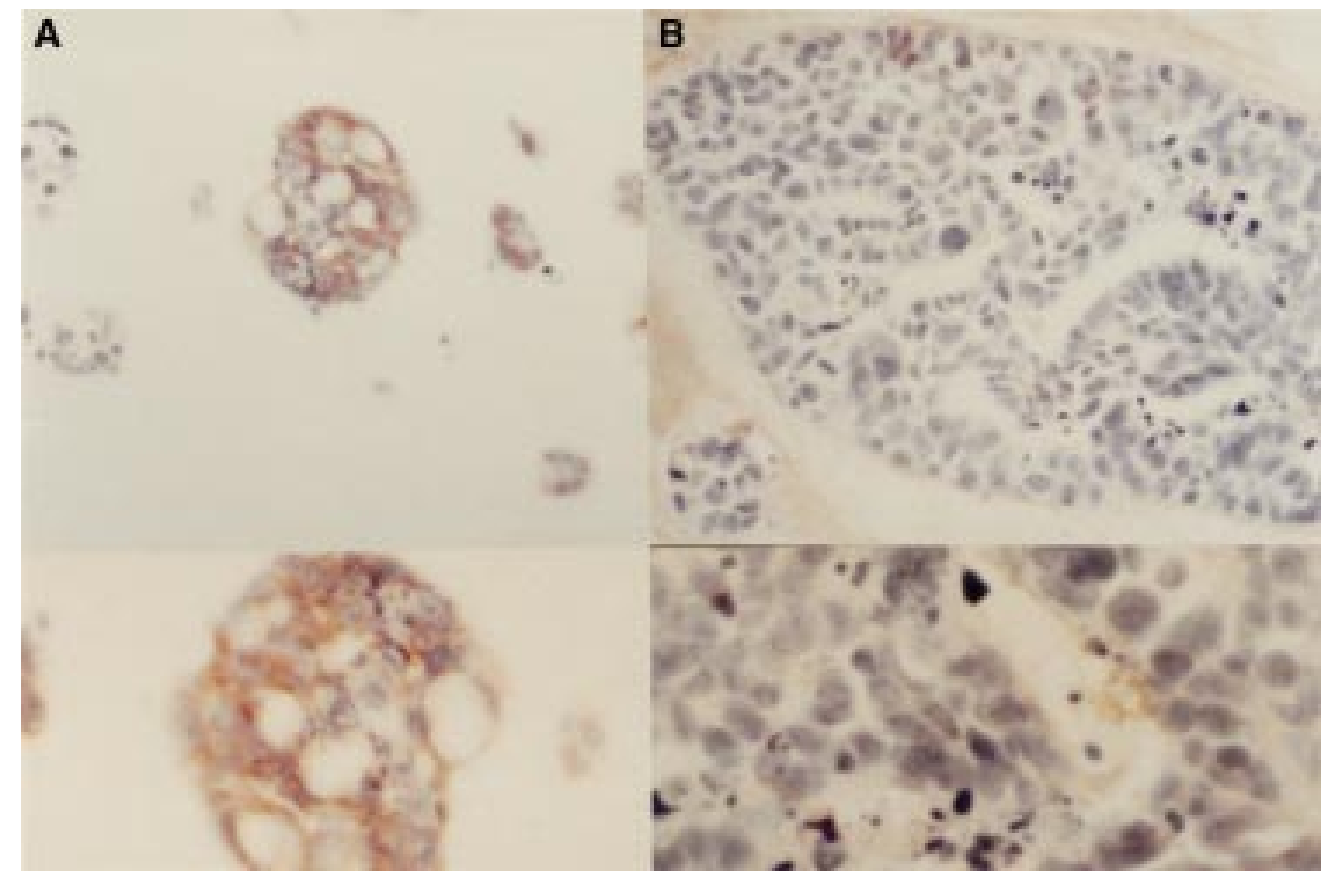

Figure 2 The cell lines are labelled with E-cadherin antibodies after 15 days growth in collagen gels (magnification, $\times 400-700$ ). (A) Caco-2, small cell clumps with mucin production and moderate E-cadherin expression. (B) SW 480, little or no E-cadherin is expressed in the poorly organised cell clumps. (High power inserts are placed above and below the central photographs; magnification, $\times 500-1000$.)

lular matrix. Therefore, we postulated that altered cell-cell adhesion may, in part, explain some of these observations.

\section{Materials and methods \\ CELL CULTURE}

The HCA-7 cells were grown routinely as monolayers in tissue culture treated plastic flasks and were fed daily by a complete change of Dulbecco's modified Eagles medium supplemented with $110 \mu \mathrm{g} / \mathrm{ml}$ sodium pyruvate, $100 \mu \mathrm{g} / \mathrm{ml}$ kanamycin, and $10 \%$ fetal calf serum. Cells were incubated at $37^{\circ} \mathrm{C}$ under $7.5 \%$ carbon dioxide in a Heraeus gassing incubator. Cell passages were as follows: colony 1 (passages 24-34), colony 3 (passages 28-43), colony 6 (passages 13-22), and colony 30 (passages 22-37).

COLLAGEN GELS

A $5 \mathrm{ml}$ aliquot of cell suspension containing 500000 cells was placed in a universal container and cells were syringed through a French gauge needle size 20 to obtain a single cell suspension. Collagen solution ( $1 \mathrm{M} \mathrm{NaCl} / 1 \mathrm{M} \mathrm{Na}_{2} \mathrm{HPO}_{4} /$ $1 \mathrm{M} \mathrm{NaOH}$ solution; 8:1:1) was kept on ice and

Table 1 Phenotype of HCA-7, SW 480, SW 620, and Caco-2 cells in agarose gels

\begin{tabular}{lllll}
\hline Cell line & Proliferation & Invasion & Colony size & $\begin{array}{l}\text { Colony forming } \\
\text { units }(\text { CFU/cm }\end{array}$ \\
\hline HCA-7 & Moderate & Yes + & Moderate, round & 323 \\
Colony 1 & Low & No & Small, round & 72 \\
Colony 3 & Now & No & Small, round & 54 \\
Colony 6 & Low & No & Small, round & 3 \\
Colony 30 & Moderate & Yes + & Small, round & 130 \\
Caco-2 & Moderate & Yes + & Small, irregular & 369 \\
SW 620 & High & Yes ++ & Large, irregular & 550 \\
SW 480 & &
\end{tabular}

Proliferation: low, $<10 \%$; moderate, $<25 \%$; high, $>25 \%$ of cells labelled with Ki- 67 antibody. Invasion: no, only single cells or small round regular colonies; yes + , small irregular colonies with peripheral aggregates; yes ++ cellular "streaming" into agarose and distortion of agarose gel. Colony size: small, $<2 \mathrm{~mm}$; moderate $2-4 \mathrm{~mm}$; large, $>5 \mathrm{~mm}$

Colony forming units (CFU): number of colonies with a group of cells $\geqslant 4 / \mathrm{cm}^{2}$.
$5 \mathrm{ml}$ was added to $0.5 \mathrm{ml}$ of syringed cells. A $1 \mathrm{ml}$ aliquot of this cell/collagen solution was transferred to an organ culture dish and allowed to set at $37^{\circ} \mathrm{C}$ for $\sim 60$ minutes. The collagen gel was covered with growth medium and the remaining $5 \mathrm{ml}$ of cells added to $20 \mathrm{ml}$ of growth medium in a $75 \mathrm{~cm}^{2}$ flask.

AGAROSE GELS (ANCHORAGE INDEPENDENCE)

A $6 \%$ (wt/vol) solution of sea prep agarose (FMC, La Jolla, USA) in double distilled water was prepared by boiling in a water bath for 20-30 minutes. Cells were harvested from flasks by trypsinisation and resuspended in fresh medium. Equal volumes of each cell suspension and agarose solution were mixed, giving a final concentration of $3 \%$ agarose. Replicate amounts of each cell agarose suspension were plated out in six well plates, which were then chilled at $4^{\circ} \mathrm{C}$ for 30 minutes to allow the gels to set. Fresh medium $(2 \mathrm{ml})$ was then added to each well and changed every two days.

\section{IMMUNOHISTOCHEMISTRY}

Several anti-E-cadherin antibodies were used to assess protein synthesis; negative controls were similarly stained duplicate sections in which the primary antibody was omitted and replaced by normal isotype matched mouse immunoglobulin.

The specificity of antibody binding was confirmed by competitive incubation of the primary antibody in the presence of excess (50 mg/50 ml) immunising E-cadherin peptide and retention of staining after preabsorption with other non-specific peptides.

The distribution of cellular staining of specific immunoreactivity was classified according to its distribution in the cell membrane or cytoplasm. 
SODIUM DODECYL SULPHATE POLYACRYLAMIDE GEL ELECTROPHORESIS (SDS-PAGE) AND WESTERN BLOT ANALYSIS

Cells were washed in phosphate buffered saline (PBS) at $0^{\circ} \mathrm{C}$, centrifuged at $1000 \times g$ for five minutes, and the supernatant discarded. Protein was extracted according to standard protocols. ${ }^{23}$ One dimensional, fixed percentage resolving gels were prepared, essentially by the method of
Laemmli, ${ }^{24}$ and the proteins were transferred directly to nitrocellulose using electron transfer buffer $(25 \mathrm{mM}$ Tris/ $\mathrm{HCl}, 190 \mathrm{mM}$ glycine, and $20 \%$ (vol/vol) methanol). The blot was incubated in a 1/500 dilution of the HECD-1 antibody for two hours at room temperature. Excess unbound antibody was removed by washing the blot several times in TBST (Tris buffer solution containing $0.1 \%$ Triton) before

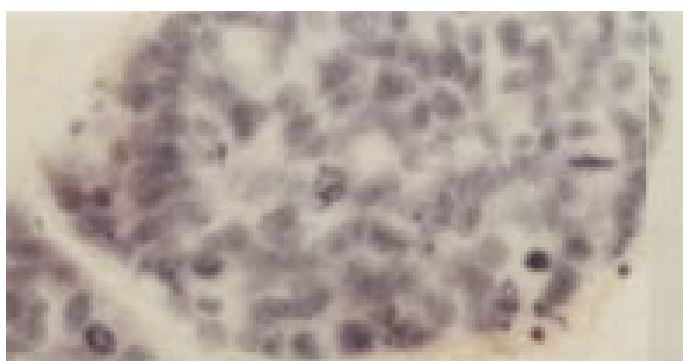

A

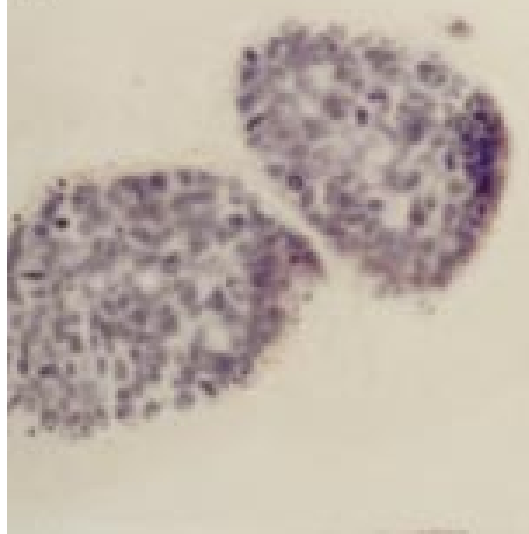

B
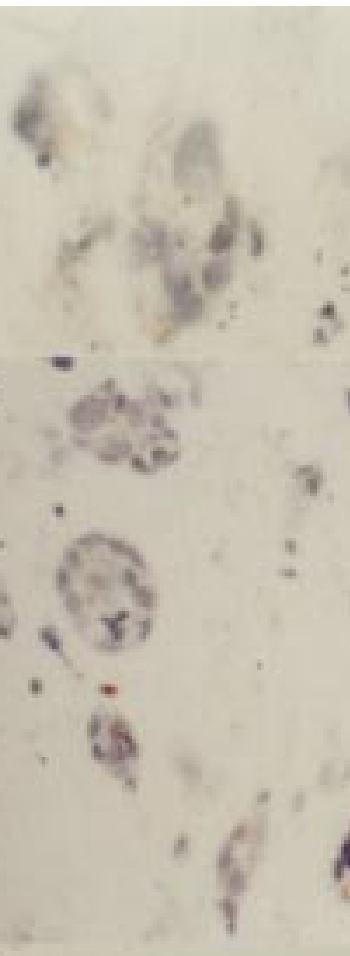

C

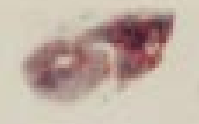

D

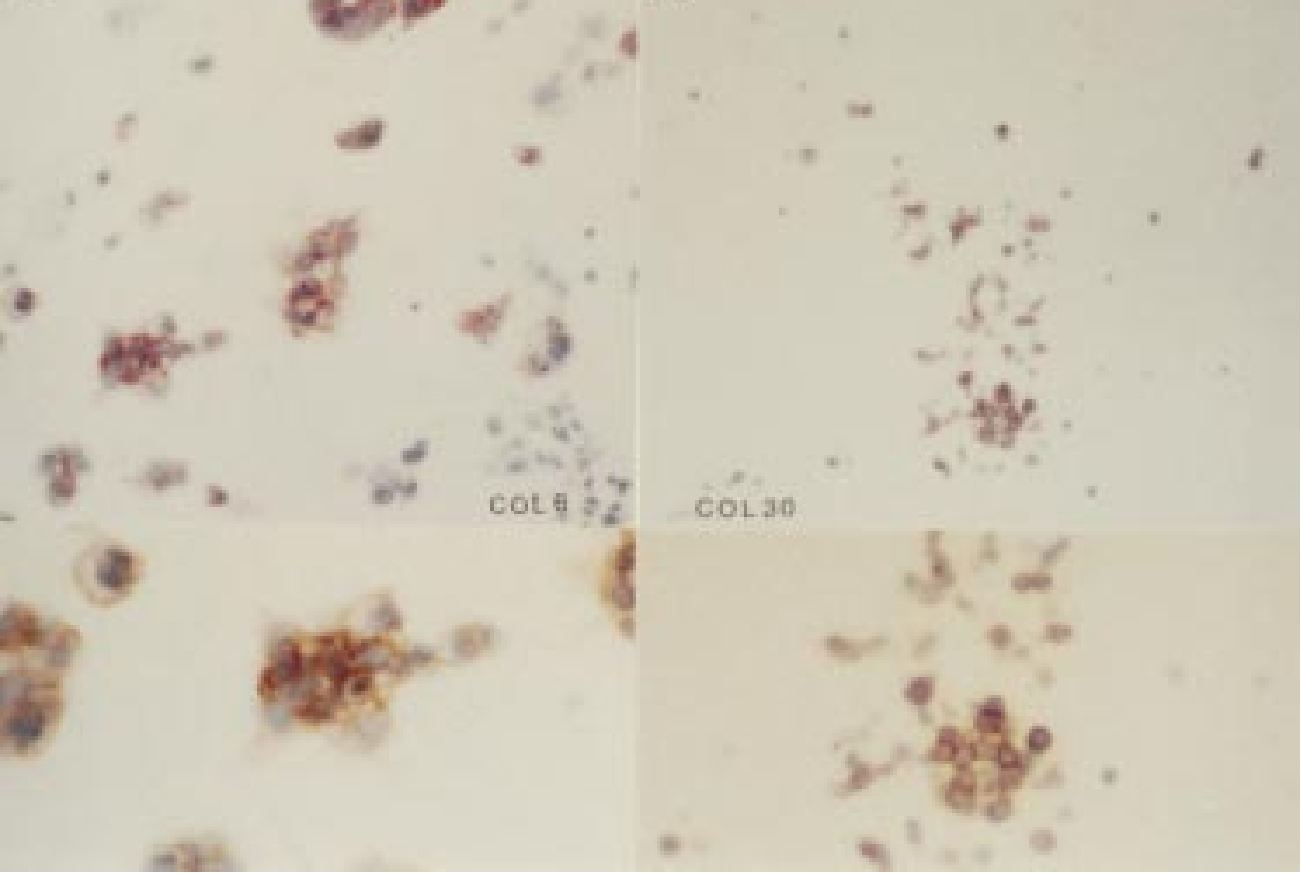

Figure 3 The HCA-7 subcolonies are labelled with E-cadherin antibodies after 15 days growth in agarose gels (magnification, $\times 400)$. (A) Colony 1, moderate sized colonies with active proliferation and clumps forming; little or no E-cadherin is demonstrable. (B) Colony 3, only a few cell clumps expressing E-cadherin are apparent. (C) Colony 6, most cells are single cells but where aggregates are present E-cadherin staining is seen. (D) Colony 30, few cells are present; one clump has E-cadherin staining but cells have dubious viability. (High power inserts are placed above and below the central photographs; magnification, $\times 500-1000$.) 


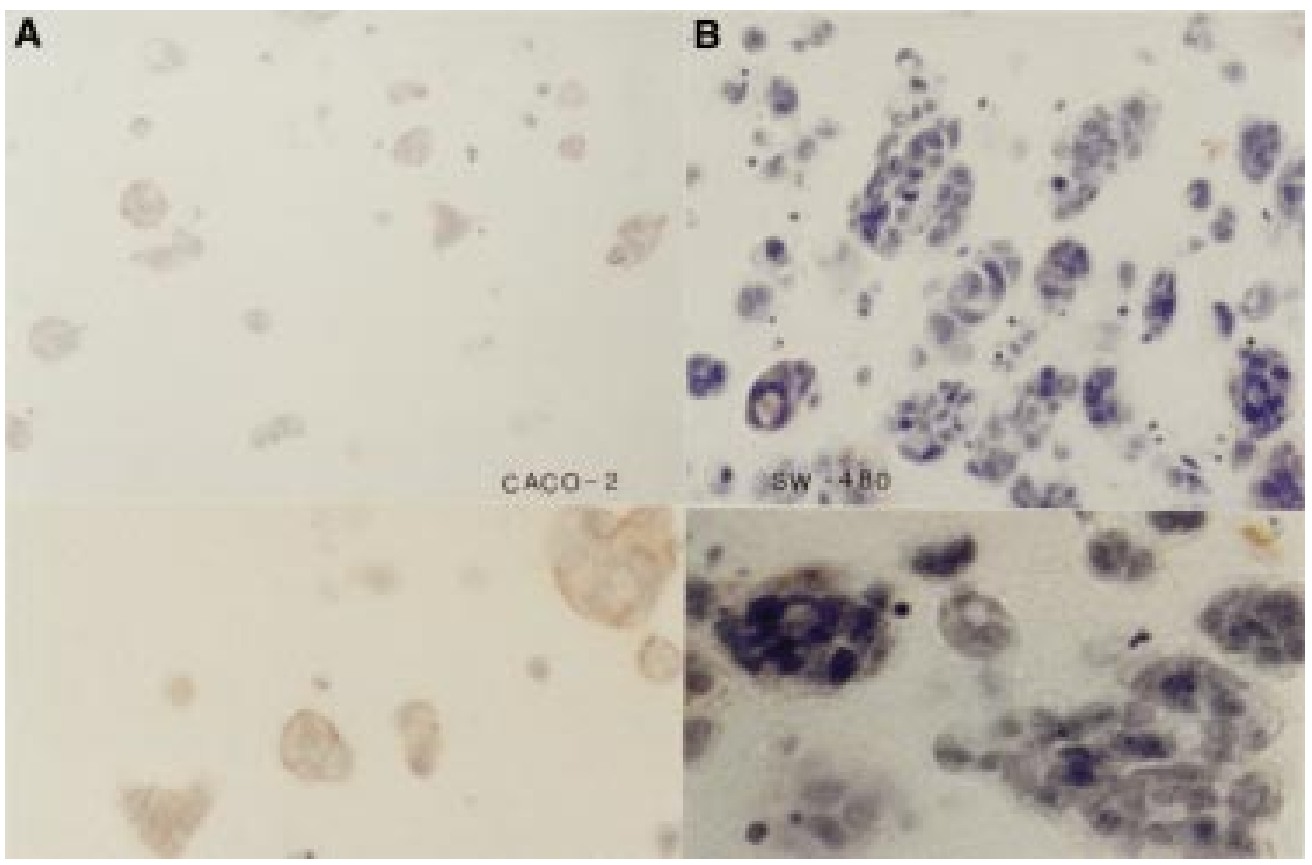

Figure 4 The cell lines are labelled with E-cadherin antibodies after 15 days growth in agarose gels (magnification, $\times 400$ ). (A) Caco-2, some small cell clumps with weak E-cadherin expression are present but viability is dubious in many other surrounding cells. $(F) S W 480$, cells are invasive and there is a high degree of proliferation but E-cadherin is not demonstrable. (High power inserts are placed above and below the central photographs; magnification, $\times 500-1000$.)

incubating the blot in a $1 / 1000$ dilution of biotinylated swine antirabbit immunoglobulin (Dako, Copenhagen, Denmark). Incubation was continued for another five minutes with diaminobenzidine tetrahydrochloride in $0.03 \%$ (vol/ vol) $\mathrm{H}_{2} \mathrm{O}_{2}$. Negative controls included similarly processed blots in which the primary antibody had been preadsorbed to the relevant protein, or the total omission of the antibody. Cam 5.2 was used as a positive epithelial loading control. ${ }^{25}$

EXTRACTION OF RNA FROM CELL LINES AND NORTHERN BLOTTING

Poly $\mathrm{A}^{+}$mRNA was extracted using the polyAT tract System 1000 magnetosphere technology (Promega, San Diego, USA), following the manufacturer's instructions.

RNA was fractionated by electrophoresis in a $1 \%$ agarose gel with $2.2 \mathrm{M}$ formaldehyde and run in $1 \times$ MOPs (O.1 M MOPs, 0.01 M EDTA (disodium), $0.5 \mathrm{M}$ sodium acetate, $\mathrm{pH} 7.0$ ). The RNA sample was prepared by mixing $5.5 \mu \mathrm{l}$ of RNA (up to $10 \mu \mathrm{g}$ ), $1 \mu \mathrm{l} 10 \times$ MOPs running buffer, $3.5 \mu \mathrm{l}$ formaldehyde, and $10 \mu \mathrm{l}$ deionised formamide and heating to $65^{\circ} \mathrm{C}$ for 10 minutes. UV induced fluorescence of the RNA samples was visualised on a short wavelength transilluminator. The agarose gel was placed under a nitrocellulose/nylon (Hybond-N; Amersham, Middlesex, UK) filter, soaked in $\times 20$ SSC $(0.3 \mathrm{M} \mathrm{NaCl}$ and $0.03 \mathrm{M}$ sodium citrate), capillary blotted for 18 hours, and fixed by two minutes UV crosslinking at $8 \mathrm{~W}$ for nylon filters. The membrane was prehybridised in $20 \mathrm{ml}$ of prehybridisation buffer $(10 \mathrm{ml}$ deionised formamide, $4 \mathrm{ml}$ deionised $\mathrm{H}_{2} 0,4 \mathrm{ml} 50 \%$ dextran sulphate, $2 \mathrm{ml} \mathrm{10 \%} \mathrm{SDS,} 1.2 \mathrm{~g} \mathrm{NaCl}$ ) and 1 $\mathrm{mg} / \mathrm{ml}$ sheared salmon sperm DNA. After four hours prehybridisation at $42^{\circ} \mathrm{C}$, the radioactive probe containing $50 \mathrm{ng}$ of single stranded DNA labelled by random priming with $\alpha \mathrm{P}^{32}$ was added directly to the membrane and hybridised for a further 16 hours at $55^{\circ} \mathrm{C}$. Subsequently, the membrane was washed at high stringency and exposed to autoradiography film.

REVERSE TRANSCRIPTASE POLYMERASE CHAIN REACTION (PCR) AND GENOMIC PCR

First strand CDNA was generated using $10 \mathrm{U}$ of AMV (avian myeloblastic virus) reverse transcriptase (Pharmacia, London, UK) in the manufacturer's reverse transcription buffer supplemented with $10 \mathrm{U}$ of RNasin (Promega), $0.01 \mathrm{M} \beta$-mercaptoethanol, $1 \mathrm{mM}$ of dNTPs, and either $1 \mu \mathrm{l}$ of random primers or $1 \mu \mathrm{l}$ oligo $\mathrm{dT}$ were added to the mixture. The cDNA products were stored at $-20^{\circ} \mathrm{C}$ for up to one week.

Before amplification, the RNA-DNA hybrid or the genomic DNA was denatured at $94^{\circ} \mathrm{C}$ for five minutes, followed by rapid cooling to $4^{\circ} \mathrm{C}$ for five minutes.

All oligonucleotide primers were synthesised by the oligonucleotide synthesis unit (Clare Hall Laboratories, Imperial Cancer Research Fund, London, UK). PCR reactions were carried out in a final volume of $50 \mu \mathrm{l}$ containing PCR buffer $(500 \mathrm{mM} \mathrm{KCl,} 100 \mathrm{mM}$ Tris/HCl, $\mathrm{pH} 8.3,15 \mathrm{mM} \mathrm{MgCl}, 0.1 \%$ (wt/vol) gelatin), $200 \mathrm{mM}$ dNTPs, $0.5 \mu \mathrm{M}$ primers, 1-10 ng template, and 2.5 U Taq polymerase (Pharmacia). The reaction mix was overlaid with light mineral oil (Sigma, Poole, Dorset, UK) to prevent evaporation. Routine amplification reactions were performed using 30 cycles of denaturation at $94^{\circ} \mathrm{C}$ for one minute, annealing at $55-60^{\circ} \mathrm{C}$ for one minute, and elongation at $72^{\circ} \mathrm{C}$ for two minutes using a thermal cycler (Perkin-Elmer Cetus, Norwalk, USA). 


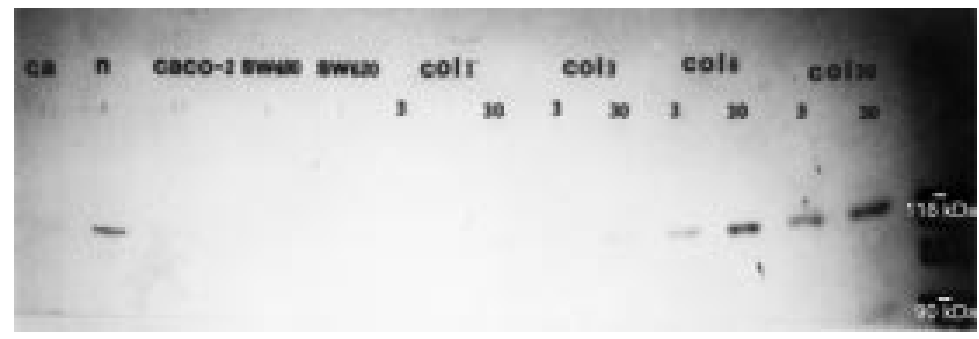

Figure 5 Western blot of E-cadherin production in the HCA-7 cell line. Positive control, normal colonic tissue (n); negative control, $S W$ 480. Concentrations of E-cadherin were highest in colonies 6 and 30 and production was also increased over time. Colonies 1, 3, and Caco-2 have low concentrations of E-cadherin.

CHROMOSOME PREPARATIONS

Each cell line was harvested when the cells reached $70 \%$ confluency. To synchronise the cultures, cells were blocked with $0.5 \mu \mathrm{M}$ fluorodeoxyuridine and $1.2 \mu \mathrm{g} / \mathrm{ml}$ uridine for 17 hours and released with $30 \mu \mathrm{g} / \mathrm{ml}$ bromodeoxyuridine five hours before harvesting. Slides were made and then G-banded by immersion in $2 \times$ SSC at $60^{\circ} \mathrm{C}$ for five to 10 minutes and stained $1: 3$ in $50 \%$ Sorenson's buffer (0.06 $\mathrm{M} \mathrm{Na} \mathrm{Na}_{2} \mathrm{HPO}_{4}$, $\left.0.06 \mathrm{M} \mathrm{KH}_{2} \mathrm{PO}_{4}\right)$. At least 20 metaphase spreads were counted and those with clear banding fully analysed. At least five cells were fully karyotyped for each cell line.

DETECTION OF SINGLE STRANDED

CONFORMATIONAL POLYMORPHISMS

The PCR reaction was performed as usual except $2 \mathrm{mM}$ non-radioactive CTP was omitted and replaced by radioactive $\alpha \mathrm{P}^{32}-\mathrm{CTP}$ $(0.2 \mathrm{mM})$. A set of primers was used to assess codons 3-5 (E-cadherin 1F: AGG CCT CCG TTT CTG GAA TC; E-cadherin 1R: CTT CAG CCA TCC TGT TTC TC). A neutral polyacrylamide gel was prepared as follows: $25 \mathrm{ml} \mathrm{MDE}$ (Quiaex, mutation detection enhancement) solution (AT Biochem, Cambridge, UK), $69 \mathrm{ml} \mathrm{H}_{2} \mathrm{O}$, and $6 \mathrm{ml} \mathrm{TBE} \mathrm{(Tris} \mathrm{buffer/}$ EDTA) were mixed, then $400 \mu \mathrm{l}$ ammonium persulphate and $40 \mu 1$ TEMED were added. To denature the sample, $2.5 \mu$ of sample was mixed with $7.5 \mu \mathrm{l}$ loading buffer (95\% formamide, $10 \mathrm{mM} \mathrm{NaOH}, 0.25 \%$ bromophenol blue, and $0.25 \%$ xylene cyanol), heated at $100^{\circ} \mathrm{C}$ for five minutes, and cooled on ice for five minutes. A $5 \mu \mathrm{l}$ aliquot of the denatured solution was loaded and electrophoresed at $6 \mathrm{~W}$ for 14 hours. Subsequently, gels were exposed to Hyperfilm at $-70^{\circ} \mathrm{C}$ overnight using intensifying screens.

DOUBLE STRANDED PLASMID DNA SEQUENCING PCR fragments were cloned into the PCRII cloning vector (Invitrogen, London, UK) and

Table 2 Summary of E-cadherin expression in the colorectal cell lines grown in monolayers, collagen gels, and agarose gels

\begin{tabular}{llll}
\hline & Monolayers & Collagen & Agarose \\
\hline HCA-7 & & & \\
Colony 1 & + & + & $-/+$ \\
Colony 3 & + & ++ & + \\
Colony 6 & +++ & +++ & ++ \\
Colony 30 & ++ & +++ & ++ \\
Caco-2 & ++ & ++ & + \\
SW 480 & - & - & - \\
\hline
\end{tabular}

E-cadherin expression: - , absent; $-/+$, minimal $(<5-10 \%$ cells $)$; + , weak $(<25 \%$ cells $) ;++$, moderate $(<50 \%$ cells $) ;+++$, strong $(>50 \%$ cells) sequenced using $\alpha \mathrm{S}^{35}$-dATP, according to the protocol in the Sequenase ${ }^{\mathrm{TM}}$ version $2.0 \mathrm{kit}$ (US Biochemicals, New York, USA), and the sequence was resolved on a standard denaturing sequencing gel. DNA analysis was carried out using the Wisconsin suite of programs on a VAX computer.

RANDOM ERRORS OF REPLICATION

RERs (microsatellite instability) can be identified using short primers containing the repeat of interest and amplifying sequences of CT repeats in tumours and comparing them with an immortalised lymphoblastoid sample derived from the same patient's white blood cells. Two microsatellite markers were chosen to evaluate each sample and primers amplified fragments of between 100 and $400 \mathrm{bp}$ in size. The primers used for each locus were as follows: for D2S123: 5'-ACATTGCTGGAAGTTCTGGC, 5'-CCTTTCTGACTTGGATACCA; for D18S58: 5'-GCTCCCGGCTGGTTTT, 5'-GCAGGAAATCGCAGGAACTT; for BAT25: 5'-TCGCCTCCAAGAATGTAAGT, 5'-TCTCATTTTAACTATGGCTC; for BAT26: 5'-TGACTACTTTTGACTTCAGC, 5'-AACCATTCAACATTTTTAACCC; and for BAT40: 5'ATTAACTTCCTACACCACAAC, 5'-GTAGAGCAAGACCACCTTG. Standard PCR conditions were used except that the annealing temperature was between $45^{\circ} \mathrm{C}$ and $50^{\circ} \mathrm{C}$ and 25 cycles were used. ${ }^{24}$ Tumours were classified as positive if at least two of the markers revealed PCR fragments not found in the normal colon.

\section{Results}

EFFECT OF COLLAGEN AND AGAR ON

COLORECTAL CELLS IN VITRO

Organisation was determined by the progressive morphological association of individual cells into glandular structures in three dimensional collagen gels. Organisation was most evident in cell line 30 and to a lesser extent cell line 6. Small hollow single layered glandular structures were present in colony 30 , but these structures were multilayered in colony 6 . In colonies 1 and 3, and the SW 480 cell line, few organised structures were evident (figs 1 and 2).

Alternatively, growth or invasion in agarose has been suggested to be an indicator of tumorigenicity in vitro. In this regard, HCA-7 cell lines 3, 6, and 30 did not infiltrate into the anchorage independent medium of agarose and cell colonies were small (fig 3). HCA-7 cell line 1 expanded slowly and concentrically in agarose gels to form moderate sized colonies, whereas the SW 480 cell line formed large infiltrative multicellular colonies with a characteristic irregular edge (table 1; fig 4).

E-CADHERIN PROTEIN AND MRNA EXPRESSION Several anti-E-cadherin antibodies were used to assess protein expression in identically prepared preparations. The DECMA-1 (Sigma, London, UK), ${ }^{9}$ 6F9 (Eurodiagnostics, Amsterdam, The Netherlands), ${ }^{26}$ and HECD-1 (Takara Biomedicals, Tokyo, Japan) ${ }^{27}$ antibodies specific for E-cadherin gave similar 


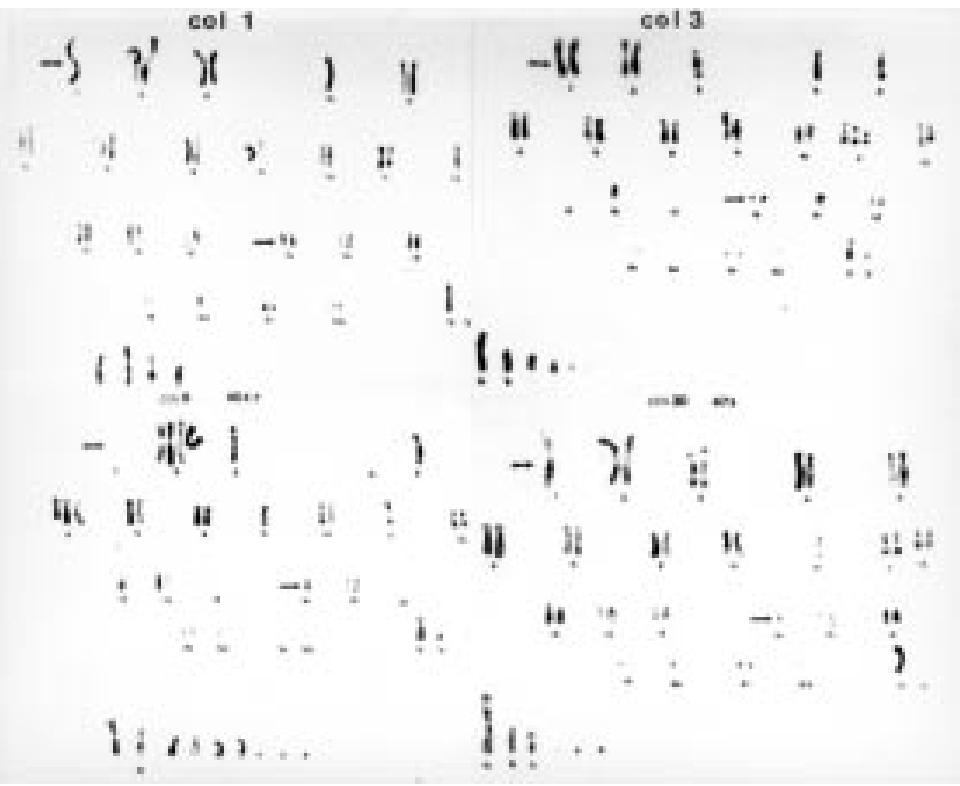

Figure 6 Karyotyping of the HCA-7 cell line colonies. The large numbers refer to the karyotype and the smaller numbers refer to the individual chromosomes 1-46. Colony 6 (col 6), absence of chromosomes 1 and 4 (arrowhead) and single copies of 3, 5, 9, 11, and 16. Colony 30 (col 30), single copies of chromosomes 1, 10, and 16 (arrowhead) in addition to double minute chromosomes at the bottom of the figure.

staining of sections and identified a $120 \mathrm{kDa}$ protein. E-cadherin is upregulated during confluency in colonies 3, 6, and 30, with the highest protein concentrations found in colonies 6 and 30 (fig 5). Colonies 6 and 30 also had greater amounts of E-cadherin mRNA as measured by northern blotting, compared with colonies 1 and 3 (data not shown). Multicellular aggregates in collagen and agar from both the HCA-7 cell lines 6 and 30 expressed abundant E-cadherin (protein and mRNA), whereas single cells expressed little or no E-cadherin (fig 1). Intriguingly, the cellular distribution of E-cadherin is basolateral in cell lines 6 and 30 in collagen, reminiscent of the normal pattern in vivo, whereas in cell lines 1 and 3 the distribution is circumferential (fig 1). Table 2 summarises the expression of E-cadherin in the different cell lines. We assessed the expression of other cell-cell adhesion molecules including CEA (carcinoembryonic antigen), CD44, and extracellular marix (ECM) interacting molecules such $\alpha 2$ integrin, $\alpha 6$ integrin, and $\beta 1$ integrin and no difference was observed between the colonies (data not shown).

KARYOTYPING

HCA-7 cell lines $1,3,6$, and 30 were hypodiploid, with a modal number of $45,43,42$, and 45 chromosomes for each metaphase, respectively. At least 20 cells were analysed for each cell line and at least five were fully karyotyped. All lines were very rearranged, especially HCA-7 colony 1 , in which aberrations most frequently involved chromosomes 1, 10, 11, 14, and 16. All four lines had clonal aberrations found in a high percentage of cells, but none were common to all lines. Furthermore, there was loss of heterozygosity of chromosome 16 in colonies 6 and 30 (fig 6).
ALTERED MORPHOLOGY INDUCED BY THE FUNCTION BLOCKING HECD-1 ANTIBODY The HECD-1 antibody binds to an epitope in the outer two E-cadherin binding domains and has been shown to inhibit cell-cell adhesion from exons 4 to $6 .^{28}$ In an attempt to assess whether this region had differential effects on the phenotype and biology of the HCA-7 cell lines, this antibody was introduced into live cell cultures. Colony 1 , and to a lesser extent colony 30, showed considerable inhibition of cell-cell adhesion when purified 1/1000 HECD-1 antibody (final concentration $40 \mu \mathrm{g} /$ $\mathrm{ml}$ ) was applied to cultures after 24 hours growth (fig 7). However, this effect was greatest at a $1 / 10$ dilution (final concentration, $4 \mathrm{mg}$ / $\mathrm{ml}$ ). In addition, the effect was also temporal because parallel plates that had an identical HECD-1 concentration of antibody added after 72 hours, as opposed to 24 hours, showed a diminished susceptibility to disaggregation with HECD-1 (fig 7; table 3). The control plates incubated with media alone revealed no disaggregation and plates incubated with the $\alpha 6$ integrin also had no visible disaggregation. Subsequently, the cells were incubated while still viable with a secondary peroxidase antibody and staining was visualised by a chromogen. The staining revealed that all dispersed and rounded up cells had very strong HECD-1 immunoreactivity over the entire surface, whereas adherent cells, with epithelial morphology, had minimal membranous immunoreactivity. Therefore, greater amounts of adherent anti-E-cadherin antibody reacted with the detaching cells than with the other cells (fig 8).

\section{RANDOM ERRORS OF REPLICATION}

Multiple DNA repeats were present in the HCA-7 cell line (fig 9). The most common gene mutation that results in RERs, the MSH2 gene mutation, was not found in the HCA-7 cell line.

SINGLE STRANDED CONFORMATIONAL POLYMORPHISMS AND SEQUENCING OF E-CADHERIN MUTATIONS

HCA-7 cell line 1 had polymorphic conformers of E-cadherin in exons 3-5 compared with cell lines 3, 6, 30, the Caco-2 cell line, and normal and neoplastic colorectal tissue (fig 10). Exons 6-7 were also examined and failed to demonstrate any conformational polymers.

Exon 4 spans the last 25 codons of the precursor peptide (155 codons long), including the important proteolytic cleavage site and the first 27 codons of the mature peptide. The sequences revealed heterogeneity of E-cadherin mutations in both colonies 1 and 30 compared with normal colonic mucosa. In particular, HCA-7 cell line 1 had a transition from GTT to GCT (valine to alanine) in codon 158 (exon 4) of the mature peptide; one further mutation was present in the same PCR fragments, CTC to CCC, resulting in a change of leucine to proline (missense mutation) in codon 149 (exon 4) of the precursor peptide. Colony 30 had two abnormalities of the mature peptide, again both present in the same fragments; in particular, 
three transitions CCC to CTC (codon 165; proline to leucine), GAA to GGA (codon 168; glutamic acid to glycine), and AAA to GAA (codon 169; lysine to glutamic acid) were identified. No other mutations were identified in the other HCA-7 cell lines or in normal or neoplastic colorectal tissue in vivo. In almost all cases, the point mutations resulted in amino
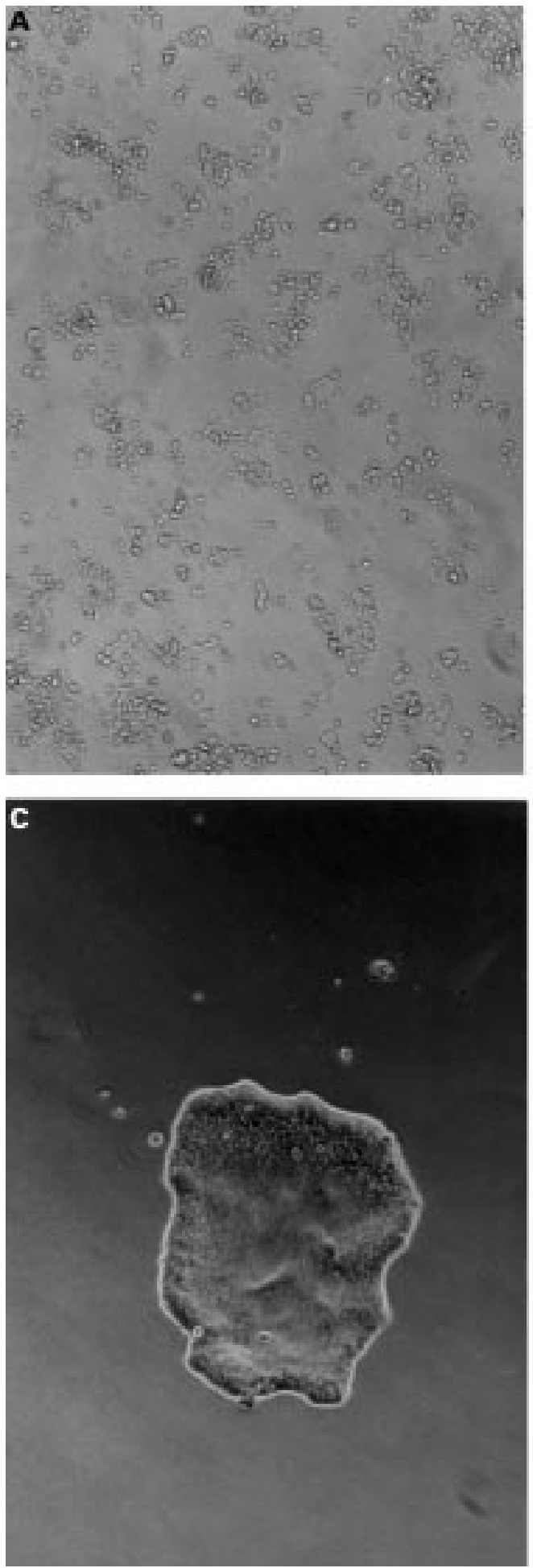

acids being changed in highly conserved regions (fig 8) with major physicochemical differences (table 4).

\section{Discussion}

In many tumours involving the skin, bladder, breast, and stomach dysfunctional E-cadherin is associated with both invasion and
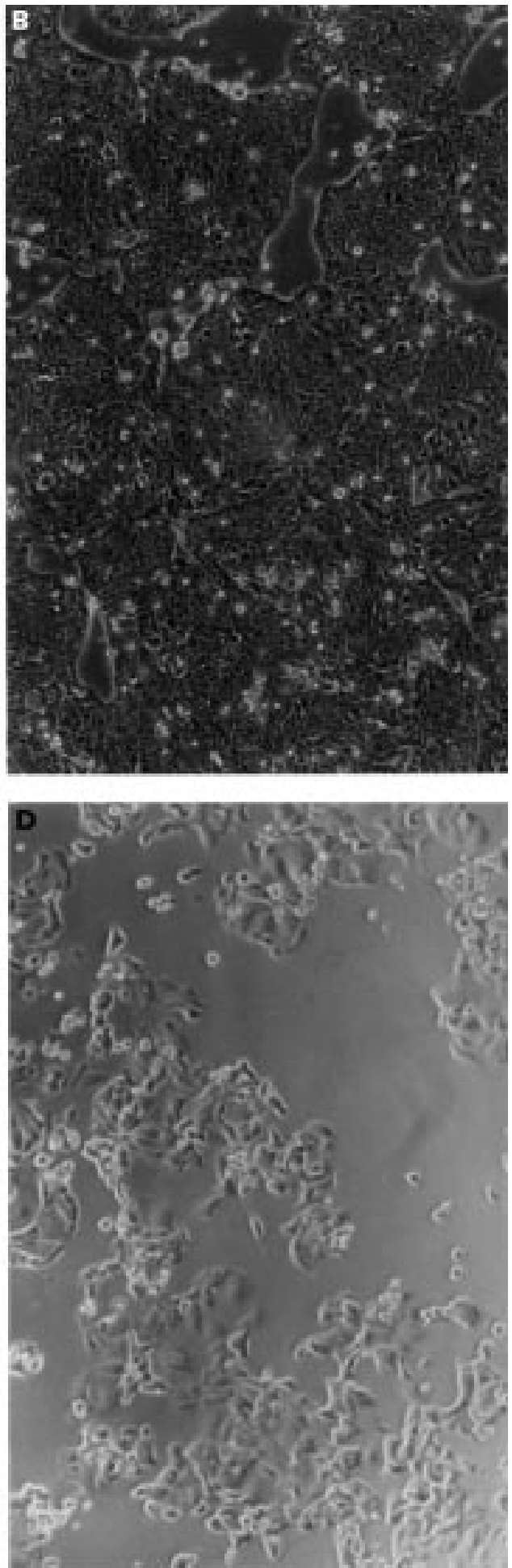

Figure 7 Morphological changes in vitro induced by the E-cadherin HECD-1 antibody after six to 12 hours (magnification, $\times 200$ ). (A) HCA-7 cell line 1, cells have become spindle shaped or become rounded and effete. (B) Colony 3 , a few loose cells are visible but most of the cells are still widely adherent. (C) Colony 6, the original morphology is maintained and only single detached cells have become rounded. (D) Colony 30, the monolayer has become severely disorganised and the epithelial shape has become more fusiform. 

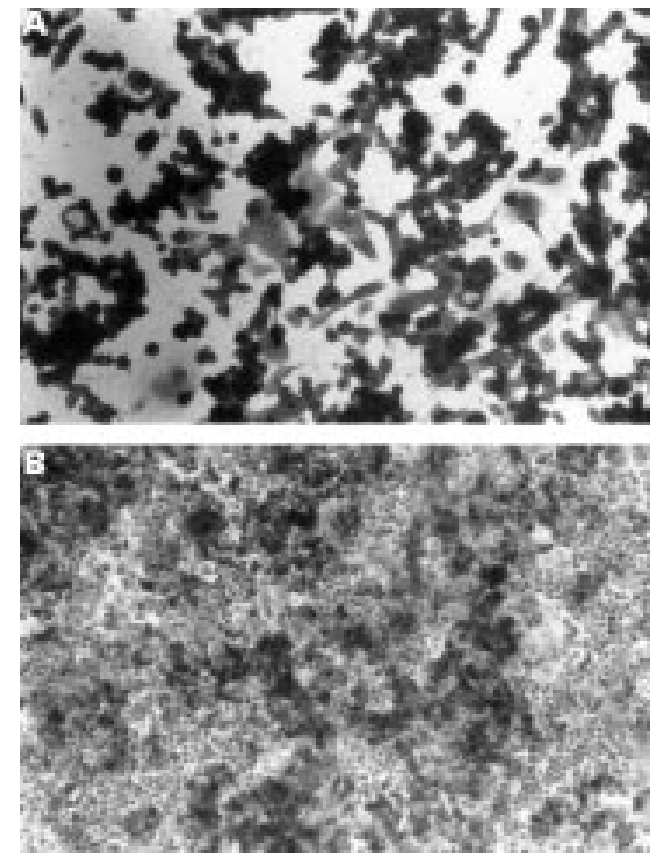

Figure 8 Cellular localisation of E-cadherin antibody on live disaggregated $\mathrm{HCA}-7$ cells (magnification, $\times 400$ ). (A) $H C A-7$ cell line 1, E-cadherin antibody is weakly present on the cell membranes of adherent live cells, whereas rounded up cells express abundant amounts of E-cadherin. (B) HCA-7 cell line 6, the anti-E-cadherin antibody is bound to very few live cells, suggesting that the epitope is expressed minimally on the apical cell surface and most is engaged in cell-cell contact in the tight junctions.

Table 3 Disaggregation with the HECD-1 antibody

\begin{tabular}{llll}
\hline & \multicolumn{3}{l}{ HECD-1 } \\
\cline { 2 - 4 } & $\begin{array}{l}1 / 10 \\
(4 \mathrm{mg} / \mathrm{ml})\end{array}$ & $\begin{array}{l}1 / 100 \\
(400 \mu \mathrm{g} / \mathrm{ml})\end{array}$ & $\begin{array}{l}1 / 1000 \\
(40 \mu \mathrm{g} / \mathrm{ml})\end{array}$ \\
\hline Colony 1 & ++++ & ++++ & +++ \\
Colony 3 & + & + & - \\
Colony 6 & + & - & - \\
Colony 30 & ++ & ++ & +
\end{tabular}

Disaggregation: - , none; + , occasional cells become rounded; ++ , many cells become rounded $(>25 \%) ;+++,>50 \%$ of cells become rounded or effete; ++++ , major change in morphology of the remaining attached cells.

metastasis. ${ }^{29}$ In the colon, most reports also confirm this association. ${ }^{9}{ }^{30}$ Our results provide further direct evidence of the importance of E-cadherin in colorectal tissue. The various HCA-7 cell lines were shown to produce different amounts of E-cadherin protein by means of immunohistochemistry and western blotting. In particular, E-cadherin positive cells were usually in the better differentiated colonies. The observation of upregulated E-cadherin with differentiation in colonies 3, 6, and 30 also suggests normal gene imprinting of cell adhesion mechanisms. Furthermore, E-cadherin positive cells tended to organise into clumps in monolayer gels and glands in collagen gels, and to exhibit anchorage dependent growth on agarose gels. Conversely the E-cadherin deficient clones had increased numbers of dispersed colonies in collagen gels, which was associated with tissue invasion in agar and xenografted tumours. ${ }^{21}$

These observations are important because we have reported previously that the HCA-7 cell line does not have Ki-ras codon 12 mutations, loss of the deleted in colorectal gancer gene (DCC), or a truncated adenomatous polyposis coli (APC) gene, although all four colonies have both p53 mutations and the mutator phenotype. ${ }^{22}$ Therefore, it is likely that in this model other genomic factors distinguish the differential morphology and biology of the individual colonies. A precedent has already been made for an involvement of cell-cell adhesion molecules in modulating cancer phenotype in vitro when the other classic mutations are nullified. ${ }^{31-33}$ In this regard, it has been reported that the transfection of wild-type $\mathrm{p} 53$, DCC, and APC into colorectal cell line SW 480 leads to suppressed tumorigenicity, but interestingly these lines still retained anchorage independence, and this is consistent with our observation of absent E-cadherin expression in this cell line. ${ }^{34}$ In our studies, the colonies with detectable E-cadherin mutations were more easily disaggregated with the function blocking HECD-1 antibody, and their morphology was also altered. This latter observation indicates that, regardless of the level of E-cadherin expression, the homotypic binding domains in these cell lines are more easily inhibited by competition with the antibody. This could be interpreted to mean that higher concentrations of cadherin may be required to regulate cellular polarity and differentiation, whereas only minimal amounts of functional E-cadherin may be required for regulating adhesion. ${ }^{35}{ }^{36}$

The allelic loss of heterozygosity of the E-cadherin gene on chromosome 16q has been reported previously in other cancers, including $40 \%$ of cervical and prostrate carcinomas, $50 \%$ of breast adenocarcinomas, ${ }^{37}$ and $75 \%$ of gastric adenocarcinomas. In a recent study of cytogenetic abnormalities in colorectal tumours, loss of $16 \mathrm{q}$ (the E-cadherin locus) was a frequent occurrence. ${ }^{38}{ }^{39}$ It has been postulated that as a consequence of the loss of heterozygosity (LOH) the decreased E-cadherin transcription may result in major morpho-spatial dysregulation. ${ }^{40}{ }^{41}$ It is of interest that the $16 \mathrm{q}$ allele is lost in $\sim 45 \%$ of the HCA-7 cell line 6 cells and $40 \%$ of cell line 30 cells, possibly suggesting a role for E-cadherin as an oncosuppressor gene, although our data suggest that the wild-type allele may be preserved. ${ }^{42}$ The rearrangement of $16 \mathrm{q}$ that occurs in HCA-7 cell line 1 is a new observation, and it is possible that the E-cadherin promoter may also be structurally changed, explaining in part the downregulation of production of the encoded protein.

Two of the most important functional domains of E-cadherin are the outer two extracellular domains. Decapeptides containing the outer two regions LFGHAVSSNG in E-cadherin inhibit adhesive function, but interestingly E-cadherin without the extracellular domain may still weakly remodel (polarise) the membrane, ${ }^{43}$ suggesting a diverse and complex transduction pathway. The first 20 codons of E-cadherin are even more highly conserved than the extracellular domains, but little is known about their role in E-cadherin function. It has also been reported that a dysfunctional external domain may act as a 


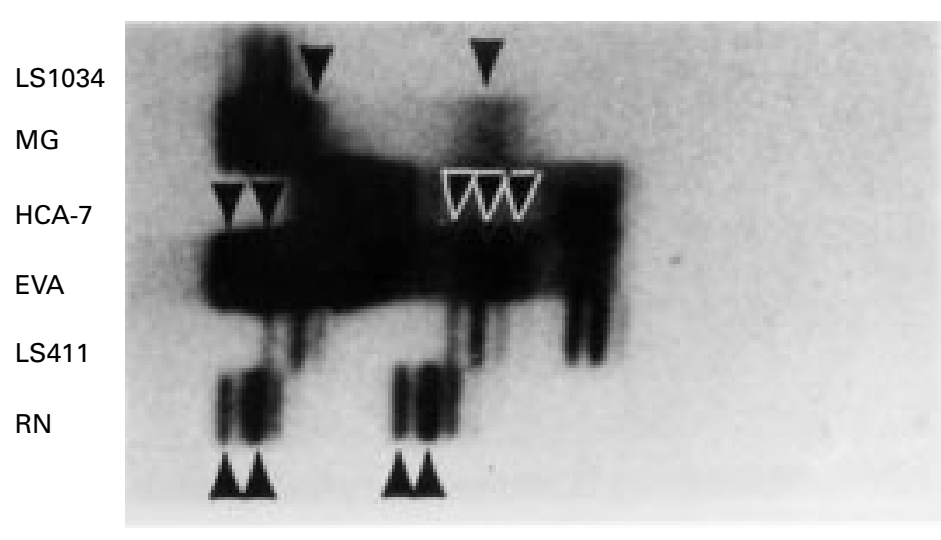

Figure 9 Microsatellite instability of the HCA-7 cell line. The HCA-7 parent cell line exhibited extra fragments of $C T$ dinucleotide repeats not comparable with the patient's paired lymphoblastoid cell line "EVA". Positive control, LS411/RN; negative control, LS1034/MG
Chicken N-cadherin

Mouse P-cadherin

Mouse E-cadherin

Human E-cadherin
DQKKIED I IFPWQQYKD S SHLKRQKR . DWVIPP INLPENSRGP LTRGTVQGGKDAMHSPP TRILRRRKR. EWVMP P IFVPENGKGP DPASESNPELLMFPSVYPG LRRQKR.DWVIPPISCPENEKGP HQASVSIQAELLTFPNSSPGLRRQKR. DWVIPP I SCPEENEKGP
Figure 10 Homology map of cadherins across species in exons 3-5. Amino acids underlined are sites of human E-cadherin mutations in the HCA-7 cell lines.

Table 4 Amino acid changes in E-cadherin as a result of point mutations

\begin{tabular}{|c|c|c|c|}
\hline Colony & Original amino acid & Mutation & Codon site \\
\hline \multirow[t]{2}{*}{ Colony 1} & $\begin{array}{l}\text { Leucine }(\mathrm{L})(131 \mathrm{Da}) \text { pKa } 7 \\
\text { (medium size and hydrophobic) }\end{array}$ & $\begin{array}{l}\text { Proline }(\mathrm{P})(115 \mathrm{Da}) \text { pKa } 7 \\
\text { (small and non-hydrophobic) }\end{array}$ & $149(4 / 12)$ \\
\hline & $\begin{array}{l}\text { Valine }(\mathrm{V})(117 \mathrm{Da}) \mathrm{pKa} 7 \\
\text { (small and hydrophobic) }\end{array}$ & $\begin{array}{l}\text { Alanine }(\mathrm{A})(89 \mathrm{Da}) \mathrm{pKa} 7 \\
\text { (tiny and hydrophobic) }\end{array}$ & $158(5 / 12)$ \\
\hline Colony 3 & & No mutations detected & $(0 / 12)$ \\
\hline Colony 6 & & No mutations detected & $(0 / 12)$ \\
\hline \multirow[t]{3}{*}{ Colony 30} & $\begin{array}{l}\text { Proline }(\mathrm{P})(115 \mathrm{Da}) \text { pKa } 7 \\
\text { (small and non-hydrophobic) }\end{array}$ & $\begin{array}{l}\text { Serine }(\mathrm{L})(131 \mathrm{Da}) \mathrm{pKa} 7 \\
\text { (medium size and hydrophobic) }\end{array}$ & $165(3 / 12)$ \\
\hline & $\begin{array}{l}\text { Glutamic acid (E) (147 Da) pKa } 4 \\
\text { (small and non-polar) }\end{array}$ & $\begin{array}{l}\text { Glycine }(\mathrm{G})(75 \mathrm{Da}) \text { pKa } 7 \\
\text { (positively charged) }\end{array}$ & $168(3 / 12)$ \\
\hline & $\begin{array}{l}\text { Lysine }(\mathrm{K})(146 \mathrm{Da}) \text { pKa } 10 \\
\text { (positively charged) }\end{array}$ & $\begin{array}{l}\text { Glutamic acid (E) (147 Da) pKa } 4 \\
\text { (negatively charged) }\end{array}$ & $169(3 / 12)$ \\
\hline
\end{tabular}

$\overline{\text { Fractions in brackets under codon sites indicate number of positive bacterial colonies screened. In }}$ HCA-7 cell line 1, double mutations were present, whereas, in HCA-7 cell line 30, triple mutations were present. cleavage of the E-cadherin polypeptide. ${ }^{48}$ In this circumstance, E-cadherin is incorporated into the cell membrane but has diminished function. It is therefore possible that the mutation of colony 1 in the precursor peptide could result in diminished adhesive function.

To date, point mutations of E-cadherin have been shown in clinical cases of gynaecological cancer, lung cancer, renal cancer, and two gastric cell lines. ${ }^{40} 49$ These point mutations are also most frequent in the calcium binding domain of the first extracellular domain, but have also been reported at the 5 ' end, and lead to the loss of adhesive activity. These somatic point mutations of E-cadherin were associated with maintenance of the wild-type allele, ${ }^{40}$ such as in HCA-7 cell line 1, whereas this was not the case in cell line 30 . The frequency of point mutations in the extreme $5^{\prime}$ region of the E-cadherin gene (exon 4) suggest that this may be a mutation cluster region (MCR) similar to those in codons 428-504 of the APC gene, as well as codons 12 and 13 of the Ki-ras gene. ${ }^{50}$ Alternatively, it could also be possible that our experimental design has a bias to selecting dysfunctional mutations in this region. ${ }^{19}$ The altered E-cadherin amino acids themselves had a spectrum of mutability values; however, interestingly all mutations were transitions. Transitions can occur spontaneously because hydrogen atoms on each of the four bases can change their location to produce a tautomer. Specifically, amino $\left(-\mathrm{NH}_{2}\right)$ and keto $(-\mathrm{C}=\mathrm{O})$ groups tautomerise to form imino $(=\mathrm{NH})$ and enol $(=\mathrm{C}-\mathrm{OH})$ groups, respectively. ${ }^{51}$ One in every 1000 bases exist as transient tautomers and can form non-standard base pairs that fit into a double helix. For example, the imino tautomer of adenine can pair with cytosine and may result in $\mathrm{C}$ being incorporated into new DNA stands where $T$ would be expected, leading to a mutation if left uncorrected. Therefore, it is possible that failure of this strand repair mechanism could explain, in part, the E-cadherin mutations found in the HCA-7 cell line, although it is not clear how this relates to the mutator phenotype present in this cell line. Conversely, if the mutations were the result of the action of common carcinogens, such as alcohol and cigarette smoke, transversions would predominate. ${ }^{52}$ In addition, nitrosamines or alkylating agents frequently cause $\mathrm{G}$ to A transitions, which accounted for only $20 \%$ of our sequence alterations. ${ }^{53}$ These mutations may also represent "adaptive mutations" in vitro, whereby cells with no adhesive properties will float and be discarded during media exchanges, leaving other cells with reduced but minimal adhesion and perhaps also a growth advantage over cells with intact adhesion, such as HCA-7 cell line $6 .^{54}$

The E-cadherin palindromic promoter region (E-pal) sequence binds several nuclear binding factors (transacting elements), which are present in well differentiated cancers and normal tissue, but are downregulated in several poorly differentiated cancers. ${ }^{55}$ Nuclear factors that stimulate c-erbB2 transcription may be inhibitory to the E-cadherin gene promoter, ${ }^{56} 57$ and it is of considerable interest therefore that ent phenotypes and biology. Further minor anomalies of the $\mathrm{N}$-terminus can also reduce E-cadherin function, such as incorrect 
colon cancer and the HCA-7 cell lines 1 and 3 also produce the c-erbB 2 oncoprotein and have low concentrations of E-cadherin. ${ }^{58}$ It is possible also that mutations in the E-pal site of the cadherin promoter may explain in part E-cadherin downregulation in these cell lines, as has recently been shown in breast cell lines.

In this report, several point mutations were detected that resulted in qualitative changes in E-cadherin in vitro. These colonies can be shown to have a temporally related decrease in function using an inhibitory binding assay, ${ }^{17}{ }^{18}$ confirming the prime importance of intact E-cadherin in maintaining a differentiated phenotype. As a result of this work, it can be said that: "cadherins show a dynamic spatiotemporal pattern of expression associated with morphogenetic events". ${ }^{11}$

One of the hallmarks of epithelial tumour cells is their phenotypic heterogeneity and the subsequent instability of these phenotypes over time. ${ }^{259}$ It is one of the major lessons from the study of the various HCA-7 cell lines that the E-cadherin gene is differentially affected in chromosomal copy number, nucleotide sequence, transcriptional activation, and function and that this is associated with such different phenotypes and biology ${ }^{60}$. In addition, the HCA-7 cell lines have a molecular profile including a "positive" RER phenotype and p53 mutations, which make them an ideal model of colitis or hereditary non-polyposis coli cancer tumours.

We would like to thank S Kirkland, K Henderson, and N Wright of the Imperial Cancer Research Fund. JJ was funded by both the Imperial Cancer Research Fund and the colorectal cancer program, University of California, San Francisco.

1 Redston MS, Papadopoulos N, Caldas C, et al. Common occurrence of APC and K-ras gene mutations in the spectrum of colitis-associated neoplasias. Gastroenterology 1995;108:383-92.

2 Connell WR, Lennard-Jones JE, Williams CB, et al. Factors affecting the outcome of endoscopic surveillance for cancer in ulcerative colitis. Gastroenterology 1994;107:934-44.

3 Hardy R, Brown H, Meltzer S, et al. Pathogenesis of colorectal cancer: the enigma of the instable genetic code. BMF [In press.]

4 MacDonald T, Horton MA, Choy MY, et al. Increased expression of laminin/collagen receptor (VLA-1) on expression of laminin/collagen receptor (VLA-1) on
epithelium of inflamed human intestine. $f$ Clin Pathol 1990;43:313-15.

5 Hermiston ML, Gordon JI. In vivo analysis of cadherin function in the mouse intestinal epithelium: essential roles in adhesion, maintenance of differentiation and regulation of programmed cell death. F Cell Biol 1995;129:489-506.

6 Hermiston ML, Gordon JI. Inflammatory bowel disease and adenomas in mice expressing a dominant negative N-cadherin. Science 1995;270:1203-7.

7 Hugot J, Puig P, Rousseau C, et al. Mapping of a susceptibility locus for Crohn's disease on chromosome 16. Nature 1996;379:821-3.

8 Parkes M, Satsangi J, Lathrop GM, et al. Susceptibility loci in inflammatory bowel disease. Lancet 1996;348:1588.

9 Richards FM, McKee SA, Rajpar MH, et al. Germ-line E-cadherin gene (CDH1) mutations predispose to familial E-cadherin gene (CDH1) mutations predispose to familial
gastric and colorectal cancer. Hum Mol Genet 1999;4:60710 .

10 Jankowski J, Bedford F, Boulton R, et al. Alterations in classical cadherins associated with progression in ulcerative and Crohn's colitis. Lab Invest 1998;78:1155-67.

11 Takeichi M. Cadherin cell adhesion receptors as a morphogenetic regulator. Science 1991;251:1451-5.

12 Tsukita S, Itoh M, Nagafuchi S, et al. Submembranous junctional plaque proteins include potential tumour suppressor molecules. F Cell Biol 1993;123:1049-53.

13 Behrens J, Vakaet L, Friis R, et al. Loss of epithelial differentiation and gain of invasiveness correlates with tyrosine phosphorylation of the E-cadherin $\beta$ catenin complex in cells transfromed with a temperature sensitive v-SRC gene. f Cell Biol 1993;120:757-66.

14 Kuroda S, Fukata M, Nakagawa M, et al. Role of IQGAP1, a target of the small GTPases Cdc42 and Rac1, in regula-
tion of E-cadherin-mediated cell-cell adhesion. Science tion of E-cadheri
15 Vleminckx K, Vakaet L, Mareel $M$, et al. Genetic manipulation of E-cadherin expression by epithelial tumour cells reveals an invasion suppressor role. Cell 1991; 66:107-19.

16 Takeichi M. Cadherins in cancer: implications for invasion and metastasis. Curr Opin Cell Biol 1993;5:806-11.

17 Wheelock MJ, Jensen PJ. Regulation of keratinocyte intercellular junction organisation and epidermal morphogenesis by E-cadherin. F Cell Biol 1992;117:415-25.

18 Lewis JE, Jensen PJ, Wheelock MJ. Cadherin function is required for human keratinocytes to assemble desmosomes and stratify in response to calcium. F Invest Dermatol 1994; 102:870-7.

19 Dorudi S, Sheffield J, Poulsom R, et al. E-cadherin expression in colorectal cancer; an immunohistochemical and in situ hybridisation study. Am f Pathol 1993;142:9816.

20 Jankowski J, Bedford FK, Kim YS. Changes in cadherin gene structure and regulation during epithelial development, differentiation and disease. Prog Nucleic Acid Res Mol Biol 1997:57:187-215.

21 Marsh KA, Stamp GWH, Kirkland SC. Isolation and characterization of multiple cell types from a single human colonic carcinoma: tumorigenicity of these cell types in a xenograft system. F Pathol 1993;170:441-50.

22 Jankowski J, Bedford FK, Ashworth A, et al. Quantitative and qualitative alterations in E-cadherin expression in vivo and in vitro [abstract]. Gastroenterology 1995;102:A478.

23 Sambrook J, Fritsch EF, Maniatis T. Molecular cloning laboratory manuals, 2nd ed. Boston: Cold Spring Harbour Laboratory Press, 1989.

24 Laemmli UK. Cleavage of structural proteins during the assembly of the head bacteriophage T4. Nature 1970;227: 680-5.

25 Helm RF, Gollner R, Peters M. Epithelial cytokeratins (Cam 5.2) in Pagets disease. Am f Dematopathol 1992;14: 402-7.

26 Vanderwurff AAM, Tenkate J, Vanderlinden EPM, et al. L-cam expression in normal, premalignant, and malignant colon mucosa. F Pathol 1992;168:287-91.

27 Shimoyama Y, Hirohashi S, Hirano S, et al. Cadherin cell-adhesion molecules in human epithelial tissues. Cancer Res 1989;49:2128-33.

28 Hirano S, Kimoto N, Shimoyama Y, et al. Identification of a neutral $\alpha$-catenin as a key regulator of cadherin function and multicellular organisation. Cell 1992;70:283-301.

29 Tang A, Eller MS, Hara M, et al. E-cadherin is the major mediator of human melanocyte adhesion to keratinocytes in vitro. $\mathcal{F}$ Cell Sci 1994;107:983-92

30 Pignatelli M, Liu D, Nasim MM, et al. Morphoregulatory activities of E-cadherin and beta-1 integrins in colorectal tumour cells. Br F Cancer 1992;66:629-34.

31 Scott N, Bell SM, Sagar P, et al. p53 expression and K-ras mutation in colorectal adenomas. Gut 1993;34:621-4.

32 Williams AC, Hague A, Manning AM, et al. In vitro models of human colorectal cancer. Cancer Surv 1993;16:15-29.

33 Williams AC, Browne SJ, Manning AM, et al. Transfection and expression of mutant p53 protein does not alter the in vivo or in vitro growth characteristics of the aa/c1 human adenoma derived cell line, including sensitivity to transforming growth factor beta 1. Oncogene 1994;9:1479-85.

34 Goyette MC, Cho K, Fashing CL. Progression of colorectal cancer is associated with gene defects but inhibition of tumorigenicity is accomplished by correction of any single defect via chromosome transfer. Mol Cell Biol 1992;12: 1387-95.

35 Nose A, Nagafuchi A, Takeichi M. Cadherins in cell sorting. Cell 1988;54:993-7.

36 Sasaki H, Tada A, Takeichi $\mathrm{M}$, et al. E-cadherin cell adhesion receptors as a regulator for multicellular spheroid formation of gynaecologic carcinoma cells [abstract]. Proc Annu Meet Am Assoc Cancer Res 1992;33:A191.

37 Tsuda H, Zhang Y, Shimosato Y, et al. Allele loss on chromosome 16 associated with progression of human chromosome 16 associated with progression of human 1990;87:6791-4.

38 Bardi G, Johansson B, Pandis N, et al. Cytogenetic analysis of 52 colorectal carcinomas - non-random aberration pattern and correlation with pathologic parameters. Int $\mathcal{F}$ Cancer 1993;55:422-8

39 Becker K-F, Atkinson MJ, Reich U, et al. E-cadherin gene mutations provide clues in diffuse type gastric carcinomas. Cancer Res 1994;54:3845-52.

40 Risinger JI, Berchuck A, Kohler ME, et al. Mutations of the E-cadherin gene in human gynaecologic cancers. Nat Genet 1994;7:98-102.

41 Becker KF, Atkinson MJ, Teich U, et al. Exon skipping in the E-cadherin gene transcript in metastatic human gastric carcinomas. Hum Mol Genet 1993;2:803-4.

42 Bussemakers MJG, van Bokhoven A, Mees SGM, et al. Molecular cloning and characterisation of the human E-cadherin cDNA. Mol Biol Rep 1993;17:123-8.

$43 \mathrm{Jaffe}$ SH. Cell adhesion in colon cancer. Proc Natl Acad Sci USA 1990;87:3589-92.

44 Fujimori T, Takeichi M. Disruption of epithelial cell-cell adhesion by exogenous expression of a mutated nonfunctional N-cadherin. Mol Biol Cell 1993;4:37-47.

45 Kintner C. Regulation of embryonic cell adhesion by the cadherin cytoplasmic domain. Cell 1992;69:225-36.

46 Nagafuchi A, Ishihara S, Tsukita S. The roles of catenins in the cadherin-mediated cell adhesion: functional analysis of E-cadherin- $\alpha$ catenin fusion molecules. $\mathcal{F}$ Cell Biol 1994; 127:235-45. 
47 Hermiston ML, Gordon JI. Inflammatory bowel disease and adenomas in mice expressing a dominant negative adenomas in mice expressing a

48 Ozawa M, Ringwald M, Kemler R. Uromorulin-catenin complex formation is regulated by a specific domain in the cytoplasmic region of the cell adhesion molecule. Proc Nat Acad Sci USA 1990;87:4246-50.

49 Oda T, Kanai Y, Oyama T, et al. E-cadherin gene mutations in human gastric carcinoma cell lines. Proc Natl Acad Sci USA 1994;91:1854-2.

50 Van Der Luijt R, Khan PM, Vasen H, et al. Rapid detection of translation-terminating mutations at the adenomatous polyposis coli gene by direct protein truncation test. Genomics 1994;29:1-4.

51 Stryer L. DNA mutations. In: Stryer L, ed. Biochemistry. New York: Academic Press, 1988: 475-85.

52 Harris CC. p53: at the crossroads of molecular carcinogenesis and risk assessment. Science 1993;262:1980-1.

53 Kimura H, Iyeharaogawa H, Kato T. Slippage misalignment - to what extent does it contribute to mammalian cell mutagenesis. Mutagenesis 1994;9:395400 .
54 Shapiro JA. Adaptive mutation: who's really in the garden? Science 1995;268:373-4.

55 Mayer B, Johnson JP, Leitl F, et al. E-cadherin expression in primary and metastatic gastric cancer; down-regulation correlates with cellular dedifferentiation and glandular differentiation. Cancer Res 1993;53:1690-5.

56 D'souza B, Taylor-Papadimitriou J. Overexpression of erbB2 in human mammary epithelial cells signals inhibiion of transcription of the E-cadherin gene. Proc Natl Acad Sci USA 1994;91:7202-6.

57 Edelman GM, Crossin KL. Cell adhesion molecules; implications for molecular histology. Anпu Rev Biochem 1991;60:155-60.

58 Kay EW, Mulcahy H, Walsh CB, et al. Cytoplasmic c-erbB2 protein expression correlates with survival in Dukes B colorectal cancers. Histopathology 1995;25:455-61.

59 Connell WR, Talbot IC, Harper N, et al. Clinicopathological characteristics of colorectal carcinoma complicating ulcerative colitis. Gut 1994;35:1419-23.

60 Vleminckx K. E-cadherin in colorectal tumorigensis. Cancer Res 1994;19:873-7. 